International Journal of Social Science And Human Research

ISSN(print): 2644-0679, ISSN(online): 2644-0695

Volume 04 Issue 12 December 2021

DOI: 10.47191/ijsshr/v4-i12-07, Impact factor-5.586

Page No: 3495-3505

\title{
Service Quality, a Correlation of Customer Expectation and Customer Perception of Services Received Responsiveness and Empathy in Shisong Hospital
}

\author{
Benard Berinyuy ${ }^{1}$, Lema Catherine Forje ${ }^{2}$, Lanyuy Gillian Dzekashu ${ }^{3}$ \\ ${ }^{1,2,3}$ Catholic University of Cameroon (CATUC), Bamenda
}

\begin{abstract}
Although Universal Health Coverage (UHC) is of the expectation that health services whether promotive, preventive, curative, rehabilitative or palliative, are of sufficient quality to be effective (WHO, 2010), there has been a common phenomenon in most health communities to find patients moving from one health service facility to another in search for better quality of services, which is defined by their expectation from the health institution and the perception after receiving the health services. Shisong hospital in Kumbo East Health District, Bui Division of the Northwest Region of Cameroon is no exception to these experiences, given that it competes with other health instructions in, around and away from Kumbo. While some patients perceive that the quality of services of Shisong hospital meet their expectations, some perceive that they are yet to receive a commensurate quality of services from Shisong hospital. It was important to find out if the ways employees of Shisong hospital respond and empathise with clients relate the expectations and perception of clients. And investigation was done by administering a unique close ended questionnaire to 425 clients who have used the services of Shisong hospital to test the relationship between their expectation and satisfaction with these two facets of service quality, Responsiveness and Empathy in this hospital through some sub derivatives. Correlation analysis showed that there is a moderate significant relationship between employee responsiveness with clients and customer satisfaction, and a strong significant relationship between employee empathy with clients and customer satisfaction. Based on responsiveness and empathy, service quality in Shisong hospital has been described as 'satisfactory'. The study recommends that the hospital should improve on these facets of service quality (responsiveness and empathy), given that customer satisfaction falls below their expectations, especially by raising customer perception to be 'very satisfactory', in match with the common expectation that has been 'very good'
\end{abstract}

\section{INTRODUCTION}

\subsection{Background and Research Problem.}

Just like with other business organisations, the world over, health service organisations have recently been facing serious challenges on how to get their customers to believe in their services. Given the global health challenges, the surge in the number of diseases and pandemics as well as how these challenges are handled by health experts has instilled so much scepticism in the minds of the folk customer on which health facility to go to or not to visit. This worry has been strongly based on their past and shared experiences with the health facilities. These experiences are issues related to the way these clients are handled initially from the frontline, which is the customer relation management (CRM) level of the organisation. Bitter experiences have pushed customers away while nice ones have made them want to repeat their use of the services of these organisations. It is generally vital in every case to first of all find out if there exist a relationship between the quality of these services and customer satisfaction. This is so because in some cases, organisations could be gunning from a monopolistic point, leaving customers with no objective position as to what they expected and how satisfied they are with the services they receive from such an organisation.

Shisong hospital is located in Kumbo, Bui Division of Cameroon and is one of the hospitals that serves people not just from Kumbo but from Cameroon, West and Central Africa, given that it runs the lone cardiac centre in the country and the two sub regions. This hospital competes with two other hospitals; Banso Baptist Hospital (BBH), Kumbo District hospital and a host of health centres and clinics in and around Kumbo. Going by the common man in Kumbo, some believe Shisong is the best hospital and offers the best services while some say it is otherwise. What therefore could be the relationship of the quality of services and specifically its responsiveness and empathy with this satisfaction or dissatisfaction?

\subsection{Objectives of the study}

The general objective of this study is to investigate what customers expect and how they perceive the quality of services they receive from Shisong hospital. 


\section{Service Quality, a Correlation of Customer Expectation and Customer Perception of Services Received Responsiveness and Empathy in Shisong Hospital}

And specifically:-

i. To attempt a theoretical and an empirical discussion of

a. the concepts of service and service quality

b. the relationship between service quality and customer satisfaction

ii. To investigate the expectation, perception of these variables by customers and the significance of the above mentioned relationships in the management of Shisong hospital;

iii. To come up with recommendations, from this investigation that can be included in policy to improve on the performance of this hospital and as well be used as key areas for further research in this field.

\subsection{Research questions}

- How do customers of Shisong hospital expect its quality of services to be?

- How do customers of Shisong hospital perceive the quality of services they receive from this hospital?

- Is there a significant relationship between service quality (responsiveness and empathy) and customer satisfaction in Shisong hospital?

\subsection{Hypothesis}

- H1: There is a significant relationship between service quality (responsiveness and empathy) and customer satisfaction in Shisong hospital.

- H2: Customers of Shisong hospital perceive the quality of services they receive as very satisfactory.

- H3: Customers of Shisong hospital expect its quality of services to be very good.

\subsection{Research gap}

Although many studies have been conducted on this topic, few have been done on health service management especially for Africa and Cameroon in particular. Other studies have looked at the relationship between service quality variables without breaking them into some detail for easy understanding by respondents of questionnaires while some have simply done the gap analysis between expectation and perception without looking at the level of satisfaction by customers. This study is done in Cameroon; it breaks the service quality variables for easy understanding of customers and traces the level of satisfaction by customers besides the relationship between customer expectations from the sub-variables and their satisfaction there from.

\section{LITERATURE REVIEW}

\subsection{Service and Service Quality}

Service is generally described as an economic activity whose output is not physical or tangible, and is consumed at the time of production such that it provides some value to the consumer especially at first purchase (Quinn et al 1987). Kotler et al (1999) corroborated with the above view when they saw service as an activity of benefit offered to one party by the other that is not tangible and ends with no ownership of anything. They equally pointed out the following traits of service; intangibility, inseparability, heterogeneity, perishability, ownership. In Line with the above views, Gronroos (2007) saw service as a process which consists of some intangible activities that take place normally but not necessarily in the customer employee interaction or physical resources or goods or systems of the service provider which exist as satisfactions to customer needs.

After a fair attempt at determining what a service is, it is important to move further in an attempt to determine what service quality can be. What is service quality?

The oxford dictionary defines quality as the standards of a thing when measured against similar ones; or the degree of excellence of a thing. To Anderson et al (2008) quality is the value a customer gets from a particular service or product. Mensah and Richard (2012) agreed with the above but made it clear that quality ought to be defined with the specifications of goods and services; they went forward to borrow from Bitner et al (1994) who viewed quality from a judgmental view, as customers' impression of the relative superiority or inferiority of the organisation and its services. There are mainly three approaches to quality, which are quality assurance (QA), Total quality learning (TQL) and Total quality management (TQM).

Quality Assurance (QA) is an approach to quality, which ensures that the quality of the products is in realm with the given system from input, through process to output. This system can be the known requirements and standards expected of the final product. It is a responsibility of all the functions of management and hence called a systematic approach to quality (Collins, 1994). Quality seeks to ensure an end that is justified by a means. It stands for a compatibility between planning and performance.

Total Quality Learning (TQL) on its part looks into customer satisfaction and continuous improvement of the product. It differs from Total quality management in that it carries a learning approach to continuous improvement. Rather than exploiting the existing avenues (like TQM) for continuous improvement, it seeks to know the unknown by exploiting mostly the external avenues in search of aspects that can play to the improvement of the product towards a better customer satisfaction (Sitkin, et al 1994). Comparatively, quality assurance has a mechanical and static approach whereas Total quality management is generic and expansionist. 


\section{Service Quality, a Correlation of Customer Expectation and Customer Perception of Services Received Responsiveness and Empathy in Shisong Hospital}

And finally, Total Quality Management (TQM) is built on the importance of organisational culture of designing, producing and improving products and services to the satisfaction of customers; it is mainly customer focused (Jabnoun, 2001). TQM is a combination of quality assurance (QA), which is based on standardization and Quality Learning that is based on continuous improvement towards customer satisfaction (Anderson et al; 1994). What differs TQM from QA is that TQM is based on continuous improvement towards customer satisfaction whereas QA is focused only on set standards. Although quality assurance may seem retardive for organisations, it is important to note that it remains the up-shoot of service quality in modern management. Management planning begins from quality assurance.

What then is service quality? Gronroos (1982) perceived service quality as the results of an evaluation process by consumers as they will always make comparisons between the expected services and their perception of the received services. Through a two dimensional (technical quality and functional quality) model, Gronroos (1984) studied service quality and found that the former was the expected outcome of the service where as the latter is the subjective perception of how the service is delivered. After concluding his two models with customer expectation, he concluded that each customer has his own perception of the quality of the service he receives. To him, service quality is a dependent of customer perception or experience from consuming the product or service.

In agreement with Gronroos (1984), Auka et al (2013) viewed service quality as the difference between customer expectations for service performance before the service encounter and the final perception after receiving the service (perception before and after the service). They agree with Asubonteng et al (1996) that customer expectation is a foundation for evaluating service quality. They all agree that quality is high when performance exceeds expectation and is low when performance does not meet expectation. Not really deviating from other views, Saravanakumar and Jayakrishnan (2014) viewed service quality as how the service meets requirements, expectations and satisfactions of customers.

A very popular definition and model of Service quality is that of Parasuraman et al (1988). They defined service quality as 'a global judgment or attitude relating to the superiority of a service'. Here they based their definition on customer expectation which to them is what a service provider should and not what he would offer. Service quality to them is therefore an outcome of consumers' view of service dimensions which are both technical and functional; in agreement with Gronroos(1984). Auka et al (2013) continue in this perspective but add that this outcome can be value added or quality itself. They added that the process is the role undertaken by a customer. To Parasuraman et al (1988) therefore, service quality is a form of attitude that is related but not equal to satisfaction and outcome from consumption with perceptions of performance. They clearly crowned that service quality is

'.......the overall evaluation of a specific service firm that results from comparing that firm's performance with the customers' general expectations of how firms in the industry should perform.......'

The SERVQUAL model of Parasuraman et al (1988) has stood the popular support of our time. SERVQUAL denotes the following facets of service quality; tangibility, reliability, responsiveness, assurance, and empathy in an organisation

Tangibility - Physical facilities, equipment and appearance of personnel.

Reliability - Ability to perform the promised service dependably and accurately.

Responsiveness - Willingness to help customers and provide prompt service.

Assurance (including competence, courtesy, credibility and security) - Knowledge and courtesy of employees and their ability to inspire trust and confidence.

Empathy (including access, communication, understanding the customer) - Caring and individualized attention that the firm provides to its customers (Parasuraman et al.; 1988). SERVQUAL has been seen as the instrument most utilized for its confirmatory factor analyses in most cases which has proven to be a parsimonious model that has been used in various service organizations and industries to measure service quality (Kheng et al; 2010).

Service quality in hospitals can be defined from three dimensions, which are patient, professional and management (Ovretveit, 2000). Patient quality being what patients want (individualistic); Personal quality being what they think patients need (absolute); and management quality being the use of fewest resources to satisfy needs and wants of patients and professionals with no waste, error, delay, all in respect of policy, law and regulations (Economic). This study is based on patient quality and will be focused on employee responsiveness and empathy.

\subsection{Customer satisfaction}

Customer satisfaction is a concept that looks into the feelings of an individual which results from his comparison of an actual result with an expected result - quality ( walker et al 2001). Boulding et al (1993) Conceptualised customer satisfaction into two levels, the transaction satisfaction level and the cumulative satisfaction level. The transaction satisfaction level is one in which the customer is experiencing the service for the first time and his specific evaluation of his first experience from that particular service (Munusamy et al 2010). On the other hand, cumulative satisfaction level is the customer's cumulative experience from contacts with services provided from where there exist standards from which to gauge a service quality (Johnson et al 1995) According to Sureshchandar et al (2003) customer satisfaction is defined from three general components; response, focus and time. To them, customer satisfaction is ' ..... response (emotional or cognitive) that patens to a particular focus (expectations, product consumption 


\section{Service Quality, a Correlation of Customer Expectation and Customer Perception of Services Received Responsiveness and Empathy in Shisong Hospital}

experience) and occurs at a particular moment in time (after experience or consumption)......' Yadav and Dabhader (2014), on their part defined customer satisfaction as a feeling of pleasure or distress that comes from an individual's evaluation of the service received in regard to his expectations. In general, Yuksel and Rimmington (1998) found that customer satisfaction is a post consumption evaluation by the consumer or user of the product or service. Customer satisfaction in a service setting is about the feelings of the customer on how good or bad the services are. The expectation is that satisfied customers feel comfortable with the services and dissatisfied customers feel uncomfortable with the services

\subsection{Service quality and customer satisfaction}

According to Spreng et al (1996) customers do set objectives in respect of measuring a desired value from a product or service. Customer satisfaction or perception of value is a vital predictor of their attitudes and loyalty (Chong et al 1997).

Working by the service quality dimensions of Parasuraman et al (1988), Zeithaml et al (2008), viewed that service quality is only predicted by the convenience the customer experiences from a good or service. On the contrary, Cavena et al (2007) held that convenience and reliability have no significant relationship with customer satisfaction whereas responsiveness; empathy and assurance were very much related to customer satisfaction.

Mustafa (2005) used SERVQUAL in Egypt to investigate patients' perception of service quality and realised that there was a significant relationship between service quality and patient satisfaction with hospital services.

Perception about a product or service stands as an initial predictor of customer satisfaction and latter loyalty. This perception is based on the quality of service received from the organisation. Good services encourage the customer to refer others to the organisation and as well return there for more services. Allowing a client to cast doubt on the services offered is a destruction of a reverse marketing, from which organisations gain so much in terms of turnover and profitability. It is obligatory for organisation that seek growth and competitive advantage to champion service quality projections that can cajole as many customers and possible. Service organisations such as hospitals, whose activity is to manage the key wealth of humans- which is health - must be at the fore front of service quality for man rushes to hospitals to repair, invest or reinvest in health

\subsubsection{Responsiveness and customer satisfaction}

Responsiveness stands for the willingness to help customers as well as the prompt provision of services. Employees desire and willingness to provide services as well as the promptness by which these services are provided is an important aspect of service quality that has so much to do with customer satisfaction (Mangi 2009). In view of the above, Kumar et al (2010) commented that responsiveness, which also involves understanding of customer needs and wants, convenient operating hours, special attention to customers, safety in transactions, influence customer satisfaction and willingness to stay or leave the organisation. Jager et al., (2010) in a study in South Africa found out that patients were not satisfied with the responsiveness of hospitals, based on the fact that they waited for too long before being attended to in hospitals. To Mohammed and Shirly (2009) responsiveness is more about communication to customers. They saw that provision of the right information to the right person at the right time has a great influence on customer satisfaction. They concluded that prompt communication instils satisfaction in customers as they are able to make prompt and better decisions, based on the timely feedback they get from this promptness. Most clients such as those of hospitals rush there with physical pain. Their prior objective is to get rid of the excruciating pain. It is but very necessary for organisations especially hospital personnel to be very aware of this and face the situation as early as possible with a vivid understanding of the case in hand. A fast and reliable reception or attendance to a client (responsive), which relieves the client of the worry, leaves him with satisfaction. Such a client will be very ready to return to the organisation in a next need.

\subsubsection{Empathy and customer satisfaction}

Empathy stands for how caring or how employees demonstrate shared feelings with customers. This trait of service quality is demonstrated in their moral communication and understanding with each other. Above all, employees succeed in managing empathy, based on their understanding of customer needs (Ehigie, 2006). Empathy has a positive relationship with customer satisfaction. Employees that are highly skilled, recognise and detect areas of customer need in service quality are able to lure customers to be very satisfied with the organisation (Auka et al 2013). Boshoff and Gray, (2004) in their study of South African hospitals realised that empathy of nurses had a positive impact on the satisfaction and loyalty of hospitals clients.

As commonly known, one must be in someone's shoes to understand where and how the shoe pinches. In service delivery, empathy remains an in borne character in employees, through which they are able to master and determine client needs and wants. Empathy takes an employee to the right target in the mindset of the client through which the client can be served with some comfort and satisfaction. It is important for employees to possess this character, without which the organisation can lose its customers.

\section{RESEARCH METHODOLOGY}

\subsection{Population and Sample Size}

Respondents were surveyed from among customers within Kumbo who have at least used the services of Shisong hospital. 
Service Quality, a Correlation of Customer Expectation and Customer Perception of Services Received Responsiveness and Empathy in Shisong Hospital

Responses were representing expectations and perceptions of individual customers in regard to the services they experienced from this hospital.

\subsection{Sampling Technique}

The simple random sampling technique was used for the collection of data.

\subsection{Instrumentation}

The instrument used in generating primary data for this study was a uniquely designed closed ended questionnaire regarding service quality expectations and perceptions. Questions were designed using the Likert scale. This questionnaire was designed in parts; part one is focused on the demographic information of the respondents, part two on expectation and perception of variables of service quality.

\subsection{Presentation and Analysis of Data}

Data has been analysed using the SPSS software and presented in tables using correlation analysis. This software and form of presentation have been used because they are very good in analysing and presenting quantitative data in various forms so much that many different minds can interpret it with focus. It also leaves a greater chance for better comparative studies to be made. The fact that this study is meant to inform the informed as well as the uninformed, gives this software and method of analysis and presentation a better chance for the findings of this study to be disseminated in time and space for better use.

\subsubsection{Correlation analysis and Test of hypothesis}

\section{a) RESPONSIVENESS}

Table 1.a: Expected employee willingness to help patients and appraisal of employee willingness to help

\begin{tabular}{|c|c|c|c|c|c|c|c|c|}
\hline & & & \multicolumn{5}{|c|}{ EXPECTED EMPLOYEE WILLINGNESS TO HELP } & \multirow[b]{2}{*}{ Total } \\
\hline & & & GOOD & $\begin{array}{l}\text { NEUTRA } \\
\mathrm{L}\end{array}$ & POOR & $\begin{array}{l}\text { VERY } \\
\text { GOOD }\end{array}$ & $\begin{array}{l}\text { VERY } \\
\text { POOR }\end{array}$ & \\
\hline \multirow{10}{*}{$\begin{array}{l}\text { APPRAISAL } \\
\text { EMPLOYEE } \\
\text { WILLINGNESS } \\
\text { HELP }\end{array}$} & \multirow{2}{*}{$\begin{array}{l}\text { DISAPPOINTE } \\
\text { D }\end{array}$} & Count & 1 & 0 & 0 & 2 & 1 & 4 \\
\hline & & $\begin{array}{|ll|}\% & \text { of } \\
\text { Total } & \\
\end{array}$ & $.2 \%$ & $.0 \%$ & $.0 \%$ & $.5 \%$ & $.2 \%$ & $.9 \%$ \\
\hline & \multirow[t]{2}{*}{ NEUTRAL } & Count & 3 & 2 & 0 & 4 & 0 & 9 \\
\hline & & $\begin{array}{ll}\% & \text { of } \\
\text { Total } & \end{array}$ & $.7 \%$ & $.5 \%$ & $.0 \%$ & $.9 \%$ & $.0 \%$ & $2.1 \%$ \\
\hline & \multirow{2}{*}{$\begin{array}{l}\text { NOT } \\
\text { SATISFIED }\end{array}$} & Count & 7 & 0 & 3 & 10 & 0 & 20 \\
\hline & & $\begin{array}{ll}\% & \text { of } \\
\text { Total } & \end{array}$ & $1.6 \%$ & $.0 \%$ & $.7 \%$ & $2.4 \%$ & $.0 \%$ & $4.7 \%$ \\
\hline & \multirow[t]{2}{*}{ SATISFIED } & Count & 105 & 0 & 0 & 140 & 0 & 245 \\
\hline & & $\begin{array}{ll}\% & \text { of } \\
\text { Total } & \end{array}$ & $24.7 \%$ & $.0 \%$ & $.0 \%$ & $32.9 \%$ & $.0 \%$ & $57.6 \%$ \\
\hline & \multirow{2}{*}{$\begin{array}{l}\text { VERY } \\
\text { SATISFIED }\end{array}$} & Count & 30 & 2 & 1 & 114 & 0 & 147 \\
\hline & & $\begin{array}{ll}\% & \text { of } \\
\text { Total } & \end{array}$ & $7.1 \%$ & $.5 \%$ & $.2 \%$ & $26.8 \%$ & $.0 \%$ & $34.6 \%$ \\
\hline \multirow[t]{2}{*}{ Total } & & Count & 146 & 4 & 4 & 270 & 1 & 425 \\
\hline & & $\begin{array}{|ll|}\% & \text { of } \\
\text { Total } & \\
\end{array}$ & $34.4 \%$ & $.9 \%$ & $.9 \%$ & $63.5 \%$ & $.2 \%$ & $100.0 \%$ \\
\hline
\end{tabular}

From table 1.a, majority of customers $(63.5 \%)$ expected employee willingness to help at Shisong hospital to be very good, while $34.4 \%$ expected it to be good. Results showed that $32.9 \%$ of customers who expected employee willingness at Shisong hospital to be very good felt satisfied at the end of the service they received, while $26.8 \%$ felt very satisfied, $2.4 \%$ were not satisfied and $0.7 \%$ felt disappointed. 
Service Quality, a Correlation of Customer Expectation and Customer Perception of Services Received Responsiveness and Empathy in Shisong Hospital

Again, 21.9\% of those who expected employee willingness to help to be good, felt satisfied at the end while $4.7 \%$ of them felt very satisfied, and $0.7 \%$ were not satisfied. There was a statistically significant evidence at $1 \%$ level between customer expectation of employee willingness to help and their appraisal after the service ( $\mathrm{p}$-value $<0.001, \mathrm{X}^{2}=61.263$ ). The relationship between these two variables was moderate $(35.7 \%)$.

Table 1.b: Expected customer promptness in receiving information and appraisal of customer promptness in receiving information

\begin{tabular}{|c|c|c|c|c|c|c|c|c|c|}
\hline & & & \multicolumn{6}{|c|}{$\begin{array}{l}\text { EXPECTED CUSTOMER PROMPTNESS IN RECEIVING } \\
\text { INFORMATION }\end{array}$} & \multirow[b]{2}{*}{ Total } \\
\hline & & & GOOD & $\begin{array}{l}\text { NEUTRA } \\
\text { L }\end{array}$ & POOR & VERY & $\begin{array}{l}\text { VERY } \\
\text { GOOD }\end{array}$ & $\begin{array}{l}\text { VERY } \\
\text { POOR }\end{array}$ & \\
\hline \multirow{10}{*}{$\begin{array}{ll}\text { APPRAISAL } & \text { OF } \\
\text { CUSTOMER } & \\
\text { PROMTNESS } & \text { IN } \\
\text { RECEIVING } & \\
\text { INFORMATION } & \end{array}$} & \multirow{2}{*}{$\begin{array}{l}\text { DISAPPOINTE } \\
\text { D }\end{array}$} & Count & 0 & 0 & 1 & 0 & 1 & 0 & 2 \\
\hline & & $\begin{array}{ll}\% & \text { of } \\
\text { Total } & \end{array}$ & $.0 \%$ & $.0 \%$ & $.2 \%$ & $.0 \%$ & $.2 \%$ & $.0 \%$ & $.5 \%$ \\
\hline & \multirow[t]{2}{*}{ NEUTRAL } & Count & 3 & 5 & 0 & 0 & 7 & 0 & 15 \\
\hline & & $\begin{array}{ll}\% & \text { of } \\
\text { Total } & \end{array}$ & $.7 \%$ & $1.2 \%$ & $.0 \%$ & $.0 \%$ & $1.6 \%$ & $.0 \%$ & $3.5 \%$ \\
\hline & \multirow{2}{*}{$\begin{array}{l}\text { NOT } \\
\text { SATISFIED }\end{array}$} & Count & 13 & 1 & 11 & 0 & 35 & 1 & 61 \\
\hline & & $\begin{array}{ll}\% & \text { of } \\
\text { Total } & \end{array}$ & $3.1 \%$ & $.2 \%$ & $2.6 \%$ & $.0 \%$ & $8.2 \%$ & $.2 \%$ & $14.4 \%$ \\
\hline & \multirow[t]{2}{*}{ SATISFIED } & Count & 121 & 1 & 2 & 0 & 115 & 0 & 239 \\
\hline & & $\begin{array}{ll}\% & \text { of } \\
\text { Total } & \end{array}$ & $28.5 \%$ & $.2 \%$ & $.5 \%$ & $.0 \%$ & $27.1 \%$ & $.0 \%$ & $56.2 \%$ \\
\hline & \multirow{2}{*}{$\begin{array}{l}\text { VERY } \\
\text { SATISFIED }\end{array}$} & Count & 21 & 2 & 1 & 1 & 83 & 0 & 108 \\
\hline & & $\begin{array}{ll}\% & \text { of } \\
\text { Total } & \end{array}$ & $4.9 \%$ & $.5 \%$ & $.2 \%$ & $.2 \%$ & $19.5 \%$ & $.0 \%$ & $25.4 \%$ \\
\hline \multirow{2}{*}{\multicolumn{2}{|c|}{ Total }} & Count & 158 & 9 & 15 & 1 & 241 & 1 & 425 \\
\hline & & $\begin{array}{ll}\% & \text { of } \\
\text { Total } & \end{array}$ & $37.2 \%$ & $2.1 \%$ & $3.5 \%$ & $.2 \%$ & $56.7 \%$ & $.2 \%$ & $100.0 \%$ \\
\hline
\end{tabular}

From table 1.b, majority of customers $(56.7 \%)$ expected promptness in receiving information at Shisong hospital to be very good, while $37.2 \%$ expected it to be good, and $3.5 \%$ expected it to be poor. Results showed that a majority of customers (27.1\%) who expected customers' promptness in receiving information at Shisong hospital to be very good felt satisfied at the end of the service they received, while $19.5 \%$ of them were very satisfied. Also, $8.2 \%$ were not satisfied while $0.2 \%$ felt disappointed.

Again, 28.5\% of customers who expected promptness at receiving information at Shisong hospital to be good felt satisfied at the end, while $4.9 \%$ of them felt very satisfied, and $3.1 \%$ were not satisfied. There was a statistically significant evidence at $1 \%$ level between customers' expectation of promptness at receiving information and their appraisal after the service $\left(p\right.$-value $<0.001, X^{2}=$ 102.505). The relationship between these two variables was moderate $(32.1 \%)$. 
Service Quality, a Correlation of Customer Expectation and Customer Perception of Services Received Responsiveness and Empathy in Shisong Hospital

Table 1.c: Expected employee understanding customers' needs and appraisal of employee understanding customers' needs

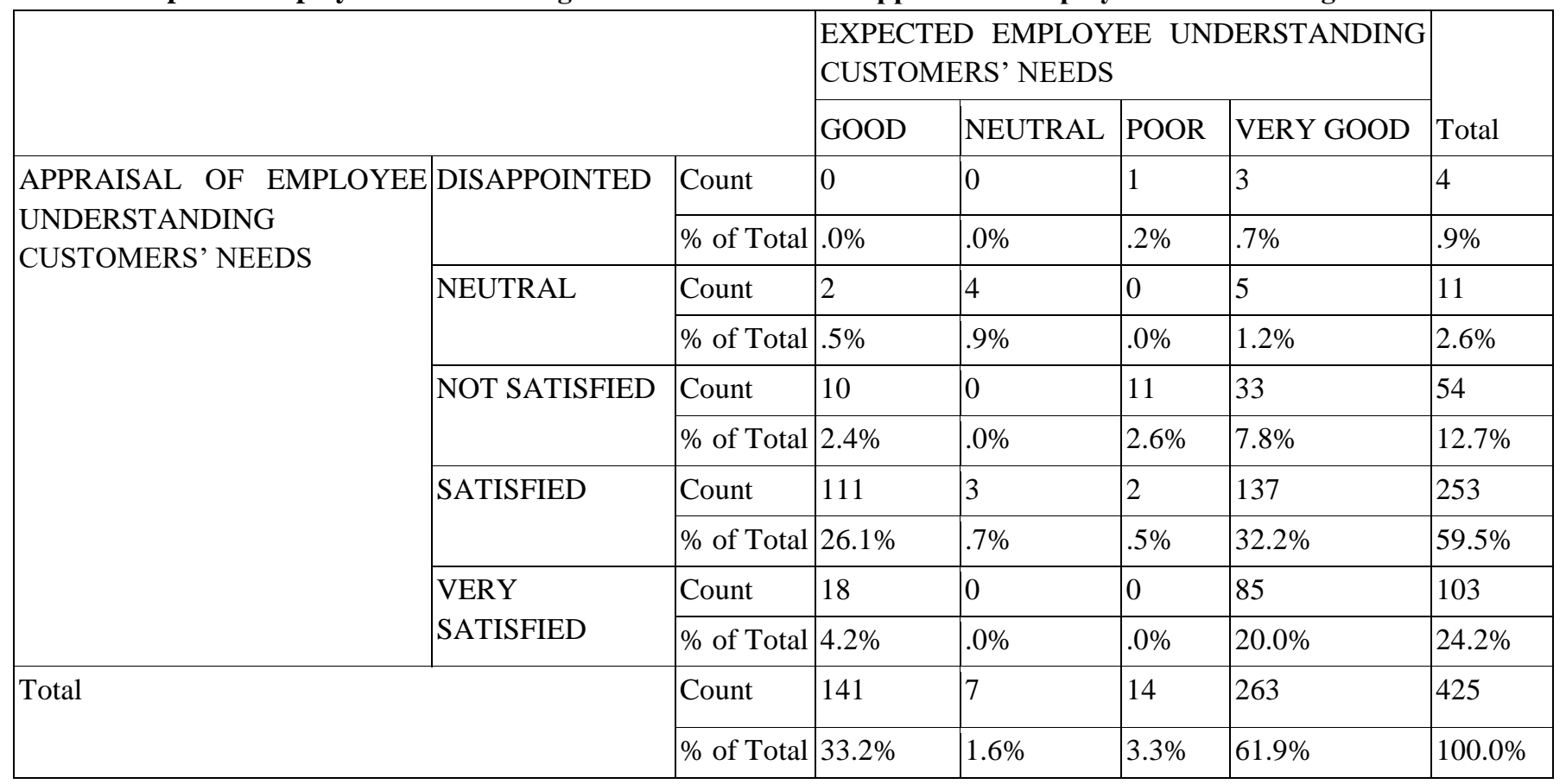

From table 1.c, majority (61.9\%) of customers of Shisong hospital expected employee understanding customers' needs to be very good, while $33.2 \%$ expected such understanding to be good. Results revealed that $32.2 \%$ of customers who expected employee understanding of customers' needs to be very good felt satisfied at the end of the service they received, while $20.0 \%$ feltverysatisfied, $7.8 \%$ were not satisfied and $0.7 \%$ felt disappointed.

Again, 26.1\%of those who expected employee understanding of customers' needs to be 'good' felt satisfied at the end, while $4.2 \%$ felt very satisfied, and $2.4 \%$ were not satisfied. There was a statistically significant evidence at $1 \%$ level that a relationship existed between expected employee understanding of customers' needs and appraisal of employee understanding of customer needs at the end of the service ( $\mathrm{p}$-value $\left.<0.001, \mathrm{X}^{2}=95.715\right)$. The relationship between the two variables was moderate $(37.3 \%)$.

\section{b) Empathy}

Table 2. a: Expected employee care and appraisal of employee care

\begin{tabular}{|c|c|c|c|c|c|c|c|}
\hline & & & \multicolumn{4}{|c|}{ EXPECTED EMPLOYEE CARE } & \multirow[b]{2}{*}{ Total } \\
\hline & & & GOOD & NEUTRAL & POOR & $\begin{array}{l}\text { VERY } \\
\text { GOOD }\end{array}$ & \\
\hline \multirow{10}{*}{$\begin{array}{l}\text { APPRAISAL OF } \\
\text { EMPLOYEE CARE }\end{array}$} & \multirow{2}{*}{$\begin{array}{l}\text { DISAPPOINTE } \\
\text { D }\end{array}$} & Count & 0 & 0 & 1 & 0 & 1 \\
\hline & & $\%$ of Total & $.0 \%$ & $.0 \%$ & $.2 \%$ & $.0 \%$ & $.2 \%$ \\
\hline & \multirow[t]{2}{*}{ NEUTRAL } & Count & 1 & 3 & 0 & 3 & 7 \\
\hline & & $\%$ of Total & $.2 \%$ & $.7 \%$ & $.0 \%$ & $.7 \%$ & $1.6 \%$ \\
\hline & \multirow{2}{*}{$\begin{array}{l}\text { NOT } \\
\text { SATISIFED }\end{array}$} & Count & 8 & 0 & 4 & 8 & 20 \\
\hline & & $\%$ of Total & $1.9 \%$ & $.0 \%$ & $.9 \%$ & $1.9 \%$ & $4.7 \%$ \\
\hline & \multirow[t]{2}{*}{ SATISFIED } & Count & 102 & 1 & 2 & 170 & 275 \\
\hline & & $\%$ of Total & $24.0 \%$ & $.2 \%$ & $.5 \%$ & $40.0 \%$ & $64.7 \%$ \\
\hline & \multirow{2}{*}{$\begin{array}{l}\text { VERY } \\
\text { SATISFIED }\end{array}$} & Count & 15 & 0 & 0 & 107 & 122 \\
\hline & & $\%$ of Total & $3.5 \%$ & $.0 \%$ & $.0 \%$ & $25.2 \%$ & $28.7 \%$ \\
\hline \multirow{2}{*}{\multicolumn{2}{|c|}{ Total }} & Count & 126 & 4 & 7 & 288 & 425 \\
\hline & & $\%$ of Total & $29.6 \%$ & $.9 \%$ & $1.6 \%$ & $67.8 \%$ & $100.0 \%$ \\
\hline
\end{tabular}


Service Quality, a Correlation of Customer Expectation and Customer Perception of Services Received Responsiveness and Empathy in Shisong Hospital

From table 2.a, a majority of customers of Shisong hospital (67.8\%) expected employee care towards customers to be very good, while $29.6 \%$ expected such care to be good. Results revealed that $40.0 \%$ of customers who expected employee care to be very good felt satisfied at the end of the service they received, while $25.2 \%$ felt very satisfied, $1.9 \%$ of customers were not satisfied and $0.7 \%$ of customers were disappointed.

Again, 24.0\% of customers who expected employee care towards customers to be good felt satisfied at the end, while $3.5 \%$ felt very satisfied, and $1.9 \%$ were not satisfied. There was a statistically significant evidence at $1 \%$ level that a relationship existed between expected employee care towards customers' needs and appraisal of employee care towards customer needs $\left(\mathrm{p}\right.$-value $<0.001, \mathrm{X}^{2}=$ 81.338).The relationship between the two variables was strong $(45.8 \%)$.

Table 2.b: Expected employee sharing customers' worries and appraisal of employee sharing customers' worries

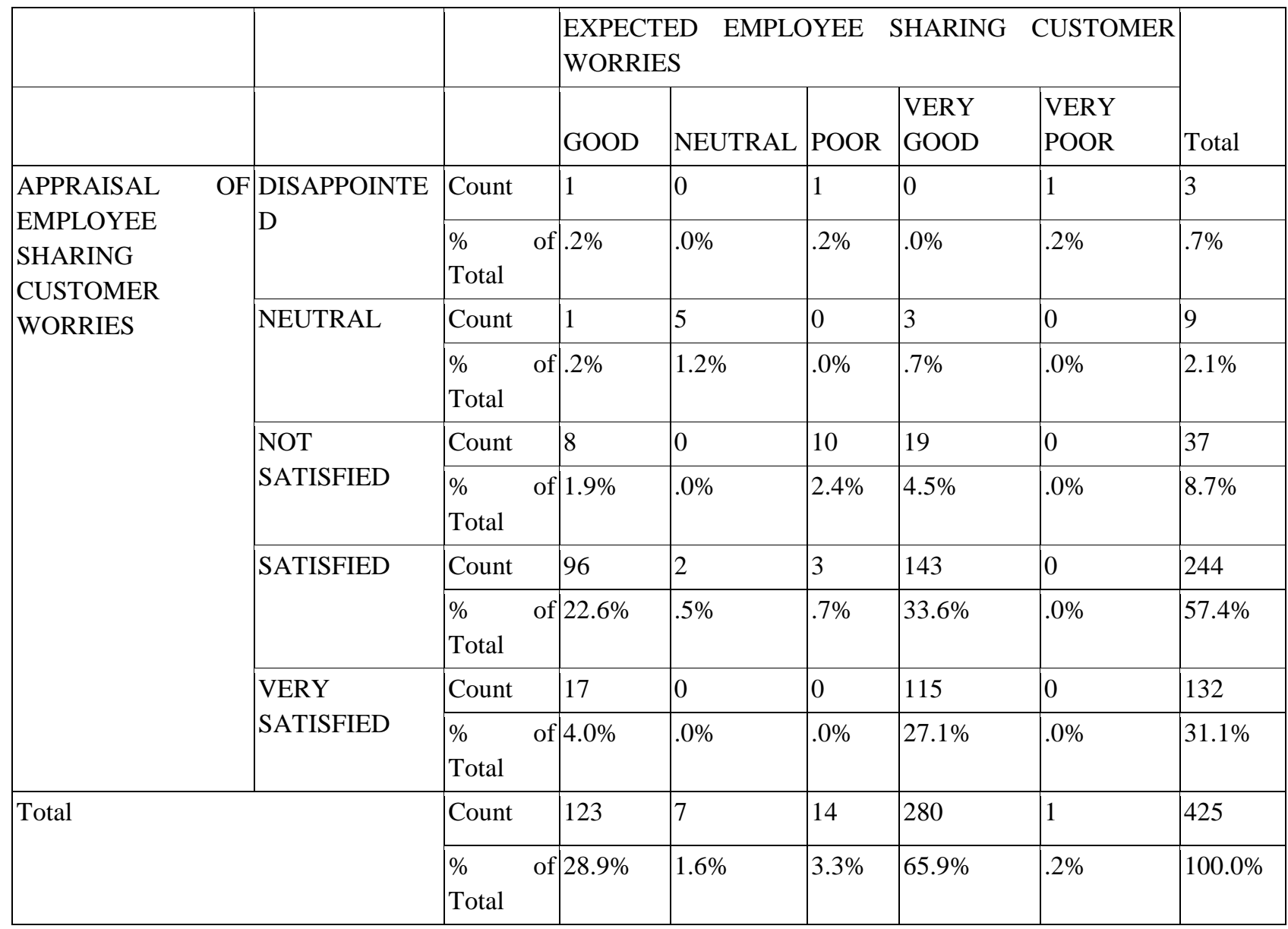

From table 2.b, majority of customers of Shisong hospital (65.9\%) expected employee sharing customers' worries to be very good, while $28.9 \%$ expected it to be good. Results revealed that $33.6 \%$ of customers who expected employee sharing customers' worries to be very good felt satisfied at the end of the service, while $27.1 \%$ felt very satisfied, and $4.5 \%$ were not satisfied.

Again, $22.6 \%$ of customers who expected employee sharing of customers' worries to be good felt satisfied at the end. While $4.0 \%$ felt very satisfied, $1.9 \%$ of customers were not satisfied, and $0.2 \%$ felt disappointed. There was a statistically significant evidence at $1 \%$ level that a relationship existed between expected employee sharing customers' worries and customer appraisal at the end of the service ( $\mathrm{p}$-value $<0.001, \mathrm{X}^{2}=125.486$ ). The relationship between the two variables was strong $(49.8 \%)$.

\subsection{Discussion of findings}

Looking at responsiveness, which had items such as employee willingness to help, promptness in receiving information, employee understanding of customer need; there proved to be a statistically significant relationship between responsiveness and customer satisfaction, which was generally described as moderate. Customer expectations on this facet of service quality proved to be very good. All levels of expectations were more that $56 \%$, with employee willingness to help having the highest level of expectation at $63 \%$. Customers were generally satisfied with responsiveness in Shisong hospital. All levels of satisfaction were more than 56\%, led by employee understanding of customer need, which was $59.5 \%$ 


\section{Service Quality, a Correlation of Customer Expectation and Customer Perception of Services Received Responsiveness and Empathy in Shisong Hospital}

From the perspective of empathy, the following areas of employee care and employee sharing with customer worry were studied. There also proved to be a statistically significant relationship between empathy and customer satisfaction that was generally described as strong. Customer expectations on the two items studied under empathy are very good. Levels of expectation were 67.8\% and 65.9\% respectively. Customers were satisfied with this service quality item in Shisong hospital at levels of $64.7 \%$ and $57.4 \%$ respectively. To crown it all, most customers $(88.0 \%)$ of Shisong hospital see its services as patient oriented. Looking at analysis from the customer expectation and perception of service quality items (responsiveness and empathy), there is a significant relationship between service quality and customer satisfaction in Shisong hospital; in agreement with hypothesis one (H1)

Most of customer expectation from these service quality items was for provision of service to be very good, most of the customers in an assessment of all the quality items (perception) proved to be satisfied with them. This result holds that hypothesis one (H2) is not true while hypothesis three $(\mathrm{H} 3)$ of the study is true.

Going by Saravanakumar and Jayakrishnan (2014) and Auka (2013) who viewed service quality as how the service meets requirements, expectations and satisfactions of customers; or the difference between customer expectations for service performance before the service encounter and the final perception after receiving the service, the results in hypothesis two (H2) show that the quality of services that is provided by Shisong hospital is satisfactory to its patients. Given that they expect the services to be 'very good' and in turn perceive them as 'satisfied' after experiencing them.

In general, the study shows that although the service quality of Shisong hospital, based on reliability and empathy is satisfactory, going by Asubonteng et al (1996), it can be described as low. Low because customers expected very high levels of service quality from Shisong hospital and are receiving a service quality level that is not commensurate (lower) to their expectations. Asubonteng et al (1996) argued that service quality is low when performance does not meet expectation. Therefore much is left to be desired from Shisong hospital to boost up its service quality level of satisfaction to customers from 'satisfied' to 'very satisfied' in line with their expectations. What will bother one so much is whether a satisfactory result in itself is not really good? Polishing up the quality of services for this hospital to an expected level is a matter of necessity, however tracing its performance in regard to this satisfactory level of satisfaction from many perspectives could polish up on how good this level of satisfaction is to Shisong hospital. The fact remains that all the items of service quality in the study have a relationship with employee satisfaction and must be handled with care.

\section{CONCLUSION, RECOMMENDATIONS AND LIMITATIONS}

\subsection{Conclusion}

In line with the study objectives, the following conclusions can be drawn in regard to Service Quality and customer satisfaction of Shisong Hospital:-

$>$ Most customers of Shisong hospital have the expectation that the quality of services of this hospital is 'very good' and worth using them.

$>$ Although they expect to have very good services from Shisong hospital, they find that the service quality in Shisong hospital is satisfactory; and low in regard to customer expectation.

$>$ There is a significant relationship between service quality and customer satisfaction in Shisong hospital

$>$ In general, customers think that the quality of services in Shisong hospital is very good, and their experiences have proven that the quality of services from this hospital is just satisfactory. However an improvement in the service quality variables in this hospital can greatly increase customer satisfaction to a high level, given that customer expectation of service quality in Shisong hospital (very Good) is generally higher than the satisfaction received (satisfied), this improvement can greatly improve on its performance - customer satisfaction, loyalty and turnover.

\subsection{Recommendations}

According to the findings of this study, Shisong hospital will have to take the following recommendations into consideration:-

$>$ Although Shisong Hospital clients generally perceive its service quality as satisfactory, all areas of service quality require improvement given that none of them received a 'very satisfied' level of perception.

$>$ The area of responsiveness requires that more should be done to improve on employee efficiency at work;

$>$ Shisong hospital could organise courses or seminars on service quality as a strong for its employees to boost their skills in the dispatch of its services.

\section{Limitations to the study}

$>$ This study happened at the time when Cameroon was going through a civil war, particularly in this area of study, Kumbo. Movement was not an easy task for both the researcher and respondents.

$>$ Clients from other areas within and nearby towns to Kumbo especially Bamenda, Ndop, Foumban, Foumbot, Nkambe, and the peripheries of Kumbo could not easily make it to Shisong hospital. 
Service Quality, a Correlation of Customer Expectation and Customer Perception of Services Received Responsiveness and Empathy in Shisong Hospital

$>$ The researcher also incurred financial difficulties in meeting the material needs of the research especially movement and printing of the required material.

$>$ Persistent power and internet cuts also marred the research seriously as it impeded on the vigour with which the researcher faced its realities

$>$ At the beginning, administrative bottlenecks at the level of the university and the hospital also gave the researcher some sleepless nights and as well killed a lot of study time

\section{REFERENCES}

1) Anderson, S. W., Pearo, L. K., \& Widener, S. K. (2008): Drivers of service satisfaction: linking customer satisfaction to the service concept and customer characteristics. Journal of Service Research, 10(4), 365-381.

2) Asubonteng, P., Mccleary, K. J. and Swan, J. (1996): SERVQUAL revisited a critical review of service quality. Journal of service marketing 10 (6), 62-81

3) Auka, D.O.; Bosire, J.N. \& Matern, V. (2013): Perceived Service Quality and Customer Loyalty in retail banking in Kenya . British Journal of Marketing Studies Vol.1, No.3, pp. 32-61, Published by European Centre for Research Training and Development UK (www.ea-journals.org) 32

4) Bitner, M.J., Booms, B.H., and Mohr, L.A. (1994): Critical Service Encounters: The Employee's Viewpoint. Journal of Marketing, 58, October, pp. 95-106

5) Blomme, R. J., Rheede, A. V and Tromp, D. M. (2010): The Use of Psychological contracts to explain turnover intentions in the Hospitality industry; A research study on the impact of gender on the turnover intentions of highly educated employees. The international Journal of Human Resource management Vol. 21(1) pp. 44-162

6) Boshoff, C. and Gray B, (2004): The relationships between service quality, customer satisfaction and buying intentions in the private hospital industry, South Africa Journal of Business Management.pg. 27-37.

7) Boulding, W.; Kalra, A.; Staelin, R. \& Zeithaml, V. A. (1993): A Dynamic Process Model of Service Quality: From Expectations to Behavioral Intentions. Journal of Marketing Research 30(1):7-2

8) Cavena, R., Corbett, L., and Lo, Y (2007): Developing Zones of tolerance for managing passenger rail services. International journal of quality reliability management, 7-31

9) Collins, D. B. and Holton, E. F. (2004):The effectiveness of managerial leadership development programs: A meta-analysis of studies from 1982 to 2001, Human Resource Development Quarterly, vol. 15, no. 2, pp. 217-248

10) Ehigie, B.O. (2006):Correlates of customer loyalty to the banks; a case study in Nigeria. International Journal of bank marketing, 24(7), 494-508

11) Gronroos, C. (1982):Strategic management of marketing and marketing in the service sector. Swedish school of economics and business administration, Helsinki:Finland

12) Gronroos, C. (1984): Service quality model and its marketing implications. Eur. Mark, J., 18 (4), 36-44

13) Grönroos,C. (2007):Service management and marketing-customer management in service competition.3 rd Edition. London: John Wiley.

14) Jabnoun, N. (2001): Control Process for QA and TQM. Work Study 52, no. 4.

15) Jager, J.; Roux, T. \& Ayadi, M. F (2010): Delivering quality service to in-and out-patients in a South African public hospital. African journal of business management 4(2):133-139

16) Johnson, M. D, Nader G \& Fornell, C. (1995): Expectations, Perceived performance and customer satisfaction for a complex service. The case of bank loans. Journal of economic psychology, 17, 163-182

17) Kheng, L.L., Mohammad, O., Ramayah, T. \& Mosahab, R (2010): The Impact of Service Quality on Customer Loyalty: A Study of Banks in Penang, Malaysia. International Journal of Marketing, Vol2. No2, 57-66

18) Kotler, P., Bowen, J.T. \& Makens, J.C. (1999): Marketing for hospitality and tourism. (2nd ed.). Upper Saddle River: Prentice-Hall.

19) Kumar, S. A., Mani, B.T.,Mahaligam, S. and Vanjikovan, M, (2010): Influence of service quality on additional loyalty in private retail banking. An empirical study. IUP Journal of management research, 9(4),21-38

20) Mangi, P. (2009): Customer satisfaction with service quality: an empirical study of public and private sector banks. IUP Journal of research, 8(9), 7-17

21) Munusamy, J.; Chelliah, S. and Mun, H. W. (2010): Service Quality Delivery and Its Impact on Customer Satisfaction in the Banking Sector in Malaysia. International Journal of Innovation, Management and Technology, Vol. 1, No.4, Pp. 398-404.

22) Mustafa, A. M. and Ilesami, O. A (2013): The Impacts of well Planned Recruitment and Selection Process on Corporate Performance in Nigerian Banking Industry (A Case Study of First Bank Plc 2004-2011). International Journal of Academic Research in Business and Social Sciences September 2013, Vol. 3, No. 9 
Service Quality, a Correlation of Customer Expectation and Customer Perception of Services Received Responsiveness and Empathy in Shisong Hospital

23) Parasuraman, A., Zeithaml. V.A., \& Berry, L.L. (1988): SERVQUAL: A multiple-item scale for measuring consumer perceptions of service quality. Journal of Retailing, 64(1), 12-40.

24) Pfeffer, J. (1998): Seven practices of successful organizations. California Management Review, Vol. 40 No. 2, pp. 96-124.

25) Quinn, J. B., Baruch, J, Paquette, P. C (1987): Technology in Services, Scientific American, Vol. 257 No. 6, pp. 5058.

26) Richard, N. and Mensah, A.A. (2012): The effect of service quality on customer retention in the banking industry in Ghana, A case study of Asokore rural bank Ltd, 12-22

27) Saravanakumar, G. \& Jayakrishnan, J. (2014): Effects of service quality on customer loyalty: empirical evidence from Cooperative Bank. International journal of business and administration research review, Vol 2, issue 4

28) Sitkin, S.B., Sutcliffe, K.M. and Shroeder R.G (1994): Distinguishing control from learning in Total Quality Management: A contingency approach. Academy of management review 9, 3: 357-454

29) Spreng, R. A., Mackenzie, S. B., and Olskavsky, R. W. (1996): A reexamination of the determinants of customer satisfaction, J, Mark. Brisbane, 112

30) Sureshchandar, G.S., Rajendran, C., and Anantharaman, R.N. (2003): Determinants of customer-perceived service quality: a confirmatory factor analysis approach. Journal of Services Marketing, 16(1), 9-34.

31) Yadav, R. K., and Dabhader N. (2014): Work Life Balance and Job Satisfaction among the Working Women of Banking and Education Sector, A Comparative Study. International Letters of Social and Humanistic Sciences Vol. 21 pp 181-201

32) Yuksel, A. and Rimmington, M. (1998): Customer-Satisfaction Measurement: Performance Counts, Cornell Hospitality Quarterly 39(6):60-70 